\title{
EKSISTENSI PESANTREN DALAM SISTEM PENDIDIKAN NASIONAL
}

\author{
Muhammad Rusdi Rasyid \\ Dosen STAIN Sorong
}

\begin{abstract}
Islamic Boarding School as an institution of Islamic education in Indonesia has become a part of nation journey. In historical aspect, boarding school takes part from struggle history and boarding school has been taking part in nation culture. In education system, boarding school as an institution of Islamic education became sub-system from national education system. But, in a long history, boarding school has not shown their existence which can give shape to expectation for all people. This case may be caused by some factors, namely history, culture of national education system that causes Islamic boarding school left behind. As we know that in 1999 as a popular year to appear desentralisation and it becomes urgent moment to change culture system and education system, including Islamic boarding school.
\end{abstract}

Keywords: Existency, Pesantren, Education

\section{Pendahuluan}

Pesantren sebagai lembaga pendidikan masyarakat Indonesia yang telah mengakar jauh sebelum Islam masuk ke Indonesia, hingga dewasa ini masih dibutuhkan oleh masyarakat. Brugmans mengadakan penelitian mengenai asal-usul pesantren ${ }^{1}$ dan berkesimpulan bahwa pesantren adalah suatu lembaga pendidikan khas berasal dari India yang sebagian dipengaruhi oleh orang Islam. Kesimpulan bahwa pesantren lebih tua dari Islam adalah

1 Lihat I.J Brugmans, Geschiedenis van het Onderwijs in Nederlandsc Indie (Sejarah Pendidikan di Hindia Belanda) Groningen, 1938. Dalam Selo Sumarjan,Social Changes in Yogyakarta,Cornell University Press, Ithaca, New York diterjemahkan oleh H.J Koesoemanto,Perubahan sosial Di Yogyakarta,(Bandung;Gajah Mada University Press). Cet. III. h. 275 
bersumber dari tradisi penghormatan santri kepada guru, tata hubungan antara keduanya tidak berdasarkan pada uang, sifat pengajaran yang murni agama, dan pemberian tanah oleh negara kepada guru dan pendeta. Kenyataan lain adalah pesantren tidak ditemukan di negara-negara Islam zaman sekarang, sedang lembaga-lembaga yang dapat dipersamakan dengan itu kini masih ada di India yang Hindu, dan di Burma serta Muanghtai yang Budha. ${ }^{2}$ Meskipun istilah pesantren belum bisa dikatakan bahwa pesantren diadopsi dari lembaga pendidikan Hindu-Budha, karena istilah pesantren tidak dikenal dalam lembaga pendidikan Hindu-Budha.

Selanjutnya pesantren telah diperkenalkan pertama kali dalam bentuk lembaga pendidikan Islam sekitar 500 tahun silam oleh Syekh Maulana Malik Ibrahim, seorang ulama besar dari Gresik pulau Jawa. ${ }^{3}$ Tetapi pendapat lain juga dikemukakan oleh Muh.Said dan Junimar Affan, mereka menyebut Sunan Ampel atau Raden Rahmat sebagai pendiri pesantren pertama di Kembang Kuning Surabaya. ${ }^{4}$ Pendapat lain juga dikemukakan oleh Kiai Machrus Aly, menurutnya, di samping Sunan Ampel (Raden Rahmat) Surabaya, ada ulama yang menganggap Sunan Gunung Jati (Syekh Syarif Hidayatullah) di Cirebon sebagai pendiri pesantren pertama, sewaktu mengasingkan diri bersama pengikutnya dalam khalwat, beribadah secara istiqamah untuk bertaqarrub kepada Allah. ${ }^{5}$ Mengenai teka-teki siapa pendiri pesantren pertama kali di Jawa, agaknya analisis Lembaga Research Islam (pesantren Luhur) cukup cermat dan dapat dipegangi sebagai pedoman. Dikatakan bahwa Maulana Malik Ibrahim sebagai peletak dasar pertama sendi-sendi berdirinya pesantren, sedang Imam Rahmatullah (Raden Rahmat atau Sunan Ampel) sebagai wali pembina pertama di Jawa Timur. ${ }^{6}$ Jika dipahami keterangan tersebut diatas, dapat kita ketahui bahwa keberadaan pesantren pertama

\footnotetext{
2 Lihat Ibid.

3 Lihat Wahjoetomo, Perguruan tinggi Pesantren: Pendidikan Alternatif Masa DEpan (Jakarta: Gema Insani Press, 1997), h. 70.

${ }^{4}$ Lihat Muh. Said dan Junimar Affan, Mendidik dari Zaman ke Zaman,(Bandun: Jemmars, 1987), h. 53.

5 Lihat Machrus Aly, Hakekat Cita Pondok Pesantren, dalam Mujamil Qomar, Pesantren dari Transformasi Metodologi Menuju Demokratisasi Institusi, (Jakarta: Erlangga, tth), h. 8.

${ }^{6}$ Lihat Pesantren Luhur,Sejarah, h. 53 dalam Mujamil Qomar, Ibid., h. 9.
} 
kali bersamaan dengan datangnya Syekh Maulana Malik Ibrahim sekaligus membawa Islam masuk ke wilayah nusantara Indonesia.

Perkembangan pendidikan Islam selanjutnya baik dalam bentuk pesantren maupun madrasah tidak begitu saja mulus, berbagai tantangan yang dihadapi oleh lembaga pendidikan ini. Meskipun kalangan pesantren juga memiliki andil yang cukup besar dalam perjuangan melawan penjajah, namun setelah kemerdekaan lembaga pendidikan ini masih dipandang sebelah mata oleh sebagian kalangan, termasuk dalam hal ini adalah masyarakat Islam yang menganggap sekolah umum lebih baik dibanding sekolah agama.

Pesantren, dengan ciri khas, variasi tipe, dan beberapa segi perbaikan yang telah dilakukan selama ini banyak yang menampilkan kesan sebagai lembaga pendidikan yang kurang teratur, suasana kumuh, dan memberi kebebasan kepada santri, bebas belajar dan bebas untuk tidak belajar. Hal ini debagai gambara tipe pesantren tradisional, yang melihat proses pendidikan sebagi kewajiban ketika menerima santri baru, tetapi tidak termotivasi menyeleksi kualitas mereka.

Dengan bergulirnya Era Reformasi setidaknya terjadi perubahan dalam dunia Pendidikan Islam terutama keberadaan pesantren. Apakah di Era Otonomi daerah yang memiliki beberapa agenda pembaruan turut memberi peluang dan harapan perkembangan kepada lembaga Pendidikan Islam terutama pesantren atau bahkan sebaliknya justru menuai tantangan.

\section{Pesantren dalam Sistem Pendidikan Nasional}

\section{Sebagai Lembaga Pendidikan Intelektual Keagamaan}

Pesantren sebagai lembaga pendidikan Islam tertua di nusantara yang merupakan ciri khas pendidikan Islam di Indonesia sejak berdirinya pada abad ketika masuknya Islam pertama kali hingga sekarang, pesantren telah bergumul dengan masyarakat. Pesantren telah berpengalaman menghadapi berbagai corak masyarakat dalam rentang waktu yang amat panjang. Pesantren tumbuh atas dukungan masyarakat bahkan pesantren berdiri atas 
permintaan dan kebutuhan masyarakat, ${ }^{7}$ Bahkan sejak awal pada masa Syekh Maulana Malik Ibrahim, pesantren telah menjadi pusat pendidikan dan penyiaran agama Islam, sehingga pesantren memiliki fungsi dan pengakuan dalam masyarakat.

Pada awalnya pesantren hanya memberikan pelajaran kepada santri terbatas pada ilmu-ilmu agama, kemudian seiring perkembangan zaman, pesantren kemudian membekali santrinya dengan pelajaran umum hingga diperbolehkan mengikuti ujian Negara yang diakui pemerintah. Tetapi karena masih dianggap kurang lengkap apa yang dimiliki seorang santri dalam menghadapi dunia masa mendatang, hingga kemudian dibekali dengan beberapa keterampilan.

Dengan demikian ada tiga " $\mathrm{H}$ " yang ditanamkan kepada santri saat sekarang ini, yaitu " $\mathrm{H}$ " pertama, head artinya kepala, maknanya mengisi otak santri dengan ilmu pengetahuan, " $\mathrm{H}$ " kedua, heart artinya hati, maknanya mengisi hati santri dengan iman dan takwa, dan " $\mathrm{H}$ " ketiga, adalah hand, artinya tangan, maknanya adalah kemampuan kerja atau keterampilan seorang santri. ${ }^{8}$ Hal tersebut merupakan bukti bahwa pesantren merupakan lembaga yang senantiasa mencetak generasi Islam yang intelektual dalam bidang ilmu pengetahuan umum, mencetak generasi Islam yang berakhlak mulia yang didasari iman dan takwa, dan mencetak generasi Islam yang memiliki keterampilan yang berdaya saing.

Sebagai lembaga dakwah, pesantren berusaha mendekati masyarakat, bekerja sama dengan mereka dalam mewujudkan pembangunan. Warga pesantren telah terlatih melaksanakan pembangunan untuk kesejahteraan masyarakat khususnya, sehingga terjadi hubungan yang harmonis antara santri dan masyarakat, antara kiai dan kepala desa. Oleh karena itu menurut Ma'shum, fungsi pesantren semula mencakup tiga aspek yaitu fungsi religius (diniyyah), fungsi sosial (ijtimaiyyah), dan fungsi edukasi (tarbawiyyah). ${ }^{9}$

\footnotetext{
${ }^{7}$ Lihat Husni Rahim, Arah Baru Pendidikan Islam Di Indonesia,(Jakarta: Logos Wacana Ilmu, 2001), h. 152.

${ }^{8}$ Haidar Putra Daulay, Pendidikan Islam Dalam Sistem Pendidikan Nasinal di Indonesia, (Jakarta: Kencana, cet.II. 2006). h. 26.

${ }^{9}$ Lihat Ali Ma'shum, Ajakan Suci, Editor Ismail S. Ahmad, M.Yoenus Noer, dan Nadirin,
} 
Fungsi lain adalah sebagai lembaga pembinaan moral dan kultural, baik di kalangan para santri maupun santri dengan masyarakat. ${ }^{10}$ Pada masa penjajahan, pesantren sebagai basis pertahanan bangsa dalam perang melawan penjajah demi lahirnya kemerdekaan. ${ }^{11}$ Oleh karena itu ternyata pesantrean memiliki peranan multidimensional baik berkaitan langsung dengan aktivitas-aktivitas pendidikan maupun di luar wewenangnya.

Berbagai observasi menunjukkan bahwa pesantren tercatat memiliki peranan penting dalam sejarah pendidikan di tanah air dan telah banyak memberikan sumbangan dalam mencerdaskan rakyat. ${ }^{12}$ Secara historis aktifitas pesantren telah melaksanakan tujuan pendidikan nasional sebagaimana tertuang dalam UU Nomor 2 Tahun 1989, yaitu "Mencerdaskan kehidupan bangsa dan mengembangkan manusia Indonesia seutuhnya, yaitu manusia yang beriman dan bertakwa terhadap Tuhan Yang Maha Esa dan berbudi pekerti luhur, memiliki pengetahuan dan keterampilan, kesehatan jasmani dan rohani, kepribadian yang mantap dan mandiri serta rasa tanggung jawab kemasyarakatan dan kebangsaan."

Eksistensi pesantren dalam pendidikan nasional dapat dilihat dalam kaitannya sebagai sub-sistem pendidikan nasional. Pendidikan nasional adalah pendidikan yang berdasarkan Pancasila dan Undang-Undang Dasar Negara Republik Indonesia Tahun 1945, yang berakar pada nilai-nilai agama, kebudayaan nasional Indonesia dan tanggap terhadap tuntutan perubahan zaman. Eksistensi pesantren semakin kuat dalam sistem pendidikan nasional setelah lahirnya UU No.2 Tahun 1989. Begitu pula Undang-Undang Republik Indonesia Nomor 20 Tahun 2003 tentang Sistem Pendidikan Nasional Bagian Kesembilan (Pendidikan Keagamaan) Pasal 30 ayat (4) menyebutkan bahwa pendidikan keagamaan berbentuk diniyah, pesantren, pasraman, pabhaja samanera, dan bentuk lain yang sejenis. Atas dasar peraturan perundang-

\footnotetext{
(t.tp.: LTN-NU DIY, 1995), h. 97.

${ }^{10}$ A. Wahid Zeni, Dunia Pemikiran Kaum Santri, Editor M. Masykur Amin dan A. Malik Ridwan, (Yogyakarta: LKPSM NU DIY, 1995), h. 92.

${ }^{11}$ Lihat Ma'shum, op.cit., h. 119.

${ }^{12}$ Departemen Agama RI., Seri Monografi Penyelenggaraan Pendidikan Formal di Pondok Pesantren, Proyek Pembinaan dan Bantuan Kepada Pondok Pesantren 1984/1985, h. 1
} 
undangan tersebut, pondok pesantren di Indonesia telah memiliki landasan legal formal untuk berkiprah secara lebih dinamis.

Sebagai salah satu bentuk pendidikan keagamaan Islam, pondok pesantren dapat berperan lebih bermakna, baik melalui jalur pendidikan formal, nonformal maupun informal. Dalam dinamikanya pondok pesantren diharapkan dapat berfungsi mempersiapkan peserta didik menjadi anggota masyarakat yang memahami dan mengartikulasikan ajaran Islam serta mengamalkan nila-nilainya di tengah-tengah masyarakat yang terus mengalami perubahan.

Dalam Bentuk lain, semangat kemandirian dan kewirausahaan pondok pesantren telah membawa santri memiliki etos kerja yang tinggi, namun tetap hidup sederhana. Kemandirian ini kemudian didukung oleh rasa ukhuwah, solidaritas dan kerja sama sesama santri dalam menopang kehidupan ekonomi mereka, baik selama nyantri maupun setelah keluar dari pondok pesantren. Oleh karena itu tantangan sosial ekonomi, dan ilmu pengetahuan dan teknologi apapun dapat mereka antisipasi dengan kerja keras dan penuh kesederhanaan. Dalam konteks pengembangan iptek tersebut, atas prakarsa dan beasiswa pemerintah c.q Direktorat Pekapontren, pada tahun 2005, sebanyak 25 (duapuluh lima) orang santri telah mengikuti program pendidikan Strata Satu (S1) di Institut Pertanian Bogor, 5 (Lima) Orang santri di Fakultas Kedokteran, 8 (delapan) orang di Fakultas Kesehatan Masyarakat Universitas Islam Negeri (UIN) Syarif Hidayatullah, dan 2 (dua) orang di Sekolah Tinggi Perikanan, Jakarta. ${ }^{13}$ Bahkan dalam bentuk pribadi, telah banyak diketahui anak santri yang telah menyelesaikan studinya di berbagai perguruan tinggi, sehingga melahirkan sarjana hukum, sarjana teknik, sarjana ekonomi, dokter, psikolog, notaris, pengacara, dan lain sebagainya.

\footnotetext{
${ }^{13}$ Lihat Departemen Agama RI, Dinamika Pondok Pesantren Di Indonesia,Direktorat Pendidikan Keagamaan dan Pondok Pesantren. Direktorat Jenderal Kelembagaan Agama Islam, 2005, h. 11.
} 


\section{Sebagai lembaga Pendidikan Dasar Dan Kesetaraan}

Keberadaan pondok pesantren di Indonesia telah banyak berperan dalam mencerdaskan kehidupan masyarakat. Perkembangan pondok pesantren sepanjang sejarah telah menunjukkan bahwa pesantren tetap eksis dan konsisten menjalankan fungsinya sebagai pusat pembelajaran ilmu-ilmu agama Islam hingga mampu menelurkan kader ulama, guru agama, dan muballigh yang sangat dibutuhkan masyarakat. Pondok pesantren sebagai lembaga yang berorientasi pada masyarakat telah meningkatkan perannya, terbukti beberapa pesantren salafiyah merealisasikan program Wajib Belajar Pendidikan Dasar Sembilan Tahun. Tujuannya adalah mengoptimalkan pelaksanaan program nasional Wajib Belajar Pendidikan Dasar Sembilan Tahun melalui pondok pesantren salafiyah. Pada tahun 2008, sebanyak 600.000 santri (tingkat ula) dan 800.000 santri (tingkat wustha) diharapkan telah mengikuti Wajar Diknas Sembilan Tahun. ${ }^{14}$

Santri yang mengikuti program tersebut memiliki kesempatan yang sama untuk melanjutkan sekolah ke jenjang yang lebih tinggi, baik ke lembaga pendidikan yang sejenis yang berciri khas agama maupun umum dengan persyaratan tertentu. Pondok pesantren yang menyelenggarakan program ini dapat menggunakan kurikulum diniyah ditambah dengan minimal 3 (tiga) mata pelajaran, yaitu Bahasa Indonesia, Matematika, IPA, dan menjadi satu kesatuan kurikulum pendidikan pondok pesantren.

Sebagai lembaga Wajib Belajar Pendidikan Dasar, p0ndok pesantren juga bisa dianggap sebagai Lembaga Pendidikan Kesetaraan. Undang-undang Sistem Pendidikan Nasional Nomor 20 Tahun 2003 dan kesepakatan bersama antara Direktur Jenderal Pendidikan Luar Sekolah dan Pemuda Departemen Pendidikan Nasional dengan Direktur Jenderal Kelembagaan Agama Nomor 19/E/MS/2004 dan Nomor DJ.II/166/04 tentang Penyelenggaraan Pendidikan Kesetaraan pada pondok pesantren adalah dasar hukum bagi pelaksanaan pendidikan luar sekolah di pondok pesantren. ${ }^{15}$

\footnotetext{
${ }^{14}$ Lihat Ibid., h. 12.

${ }^{15}$ Lihat Departemen RI, Kumpulan Undang-Undang dan Peraturan Pemerintah RI tentang Pendidikan, Dirjen Pendidikan Islam Depaqg RI, 2007, h. 43.
} 
Program Paket A, B, C setara MI/SD, MTs/SMP, MA/SMA di pondok pesantren merupakan program kesetaraan yang dilaksanakan di jalur pendidikan luar sekolah bertempat di pondok pesantren. Program Paket A, B, C setara MI/SD, MTs/SMP, MA/SMA bertujuan untuk membekali warga belajar dengan kemampuan, pengetahuan, dan sikap yang setara dengan lulusan MI/SD, MTs/SMP, MA/SMA. Progran Paket A, B, C juga menitikberatkan pada penguasaan keterampilan praktis dalam hal pengamalan agama Islam dan keterampilan berusaha. Pemilihan keterampilan berusaha difokuskan pada keterampilan bermatapencaharian yang sesuai dengan potensi dan kebutuhan setempat. ${ }^{16}$ Penguasaan keterampilan merupakan upaya menjadikan warga masyarakat berakhlak mulia, cerdas, terampil, mandiri dan berdayasaing.

\section{Sebagai Lembaga Pendidikan Tinggi}

Pendidikan Tinggi atau Ma'had 'Aliy merupakan salah satu bentuk usaha pelembagaan tradisi akademik pondok pesantren dengan cikal bakal program kajian takhassus yang telah lama berkembang. Pembentukan Ma'had 'Aliy dilatarbelakangi oleh kebutuhan untuk meningkatkan kualitas pendidikan pondok pesantren tingkat tinggi yang mampu melahirkan ulama di tengah kemajuan ilmu pengetahuan dan teknologi. Proses pendidikan di Ma'had 'Aliy sebenarnya merupakan penggabungan antara model pesantren dan model perguruan tinggi. ${ }^{17}$

Sejalan dengan arah dan kebjakan pemerintah dalam pengembangan pendidikan tinggi, Ma'had 'Aliy dipandang sebagai salah satu alternatif pendidikan tinggi agama Islam karena kekhususannya. Ma'had 'Aliy merupakan bentuk pendidikan tinggi khas pondok pesantren yang berbeda dari perguruan tinggi pada umumnya. Ma'had 'Aliy dimaksudkan sebagai

\footnotetext{
${ }^{16}$ Lihat op.cit., h. 13.

${ }^{17}$ Lihat Muhammad Maftuh Basyuni,Revitalisasi Spirit Pesantren,Gagasan, Kiprah dan Refleksi, (Jakarta: Direktorat Pendidikan Diniyah dan Pondok Pesantren, Dirjen Pendidikan Islam Depag, 2007), h. 218
} 
wadah studi lanjutan dari pendidikan dan pengajaran diniyah tingkat Ulya, Madrasah Aliyah atau yang sederajat. ${ }^{18}$

Ma'had 'Aliy berorientasi pada mutu dan kepentingan bangsa dengan tujuan mengantarkan santri menjadi ulama yang memiliki sifat pemimpin yang ideal. Memiliki sifat ilmuan, ulama professional, terbuka, bertanggungjawab, serta berdedikasi pada bangsa dan negara. Oleh karena itu, Ma'had 'Aliy berfungsi sebagai pelaksana pendidikan dan pengajaran, penelitian, dan pengabdian kepada masyarakat, serta menjadi agen perubahan sosial melalui pembentukan masyarakat madani (Civil Society).

\section{Sebagai Lembaga Pengembangan Olah Raga, Seni dan Budaya}

Ada pepatah yang sudah mashur dalam setiap pondok pesantren yang berbunyi, "Akal yang sehat terletak pada badan yang sehat". Untuk merealisasikannya, para santri tetap ada saja yang melakoninya dan mengembangkannya, meskipun kegiatan olah raga, seni, dan budaya dalam pondok pesantren relatif belum terorganisir dengan baik, dan biasanya tanpa pelatih. Akan tetapi dalam perkembangannnya semakin mengalami kemajuan yang luar biasa. ${ }^{19}$

Banyak pondok pesantren yang santri-santrinya memiliki kelompokkelompok olah raga seperti sepak bola, badminton, tennis meja, bola voli, bola basket, dan bela diri. Dalam bidang seni dan budaya, banyak juga pondok pesantren yang memiliki kelompok tilawatil Qur'an, seni musik band, samproh, dangdut, dan nasyid. ${ }^{20}$

Beberapa tahun terakhir, Direktorat Pekapontren telah memulai mencoba mengadakan Pekan Olah Raga dan Seni Pesantren Tingkat Nasional. Yang dilombakan dalam pekan olah raga dan seni tersebut bukan hanya bidang olah raga, tetapi juga seni dan budaya. Karenanya, selain meningkatkan kualitas akademik para santri dalam kajian-kajian keagamaan

\footnotetext{
${ }^{18}$ Lihat Depag RI, Dinamika, op.cit., h.14.

${ }^{19}$ Lihat Muhammad Maftuh Basyuni,Revitalisasi Spirit Pesantren, op.cit., h. 174.

${ }^{20}$ Lihat Depag RI, Dinamika, op.cit., h. 15.
} 
Islam, pondok pesantren dituntut untuk lebih mengembangkan kegiatankegiatan olah raga, seni, dan budaya.

\section{Sebagai Lembaga Pertahanan Moral dan Wawasan Kebangsaan}

Pada abad 21 ini merupakan masa global, transformasi budaya dan arus media dan informasi yang sulit dibendung, telah banyak mepengaruhi terjadinya dekadensi moral, khususnya di kalangan anak-anak dan remaja. Begitu pula budaya kekerasan dan pornografi telah masuk ke dalam ruang keluarga melalui media cetak dan elektronik. Kemajuan teknologi komunikasi telah membuat batas Negara tidak mampu membendung masuknya paham, budaya, dan gagasan-gagasan asing yang kadang-kadang menurut kita tidak cocok dengan paham, budaya, dan gagasan yang ada di Indonesia. ${ }^{21}$

Para pendidik dan psikolog telah menyebutkan bahwa pembinaan akhlak adalah proses pendidikan yang jauh lebih sulit daripada pendidikan bidang studi lain. Hal ini disebabkan karena pembinaan akhlak menyangkut sikap, tata nilai, dan termanifestasi dalam budi pekerti dan tingkah laku yang baik. Di sisi lain, faktor lingkungan juga sangat mempengaruhi pembentukan pribadi, karena pada hakekatnya manusia adalah makhluk sosial yang sangat dipengaruhi oleh lingkungan sekitarnya.

Kebiasaan bangun pagi, salat di awal waktu dan berjama'ah di pondok pesantren misalnya, bila terus dilakukan akan mengikis sifat kemalasan dan mendekatkan diri kepada keberkahan. Kebiasaan menghafal dan membaca Al-Qur'an akan membuat suasana damai dan melembutkan hati yang keras dan gelisah. Kebiasaan menuntut ilmu akan mengikis kebodohan dan mengorganisir potensi kebaikan dalam masyarakat. Sistem pendidikan seperti ini merupakan bagian dari tujuan pendidikan nasional sebagaimana tercantum dalam pasal 4 UUSPN yaitu mencerdaskan kehidupan bangsa dan mengembangkan manusia Indonesia seutuhnya, yaitu manusia beriman dan bertaqwa terhadap Tuhan Yang Maha Esa dan berbudi luhur, memiliki pengetahuan dan keterampilan, kesehatan jasmani dan rohani,

\footnotetext{
${ }^{21}$ Lihat Arief Furchan, Transformasi, op.cit., h. 17.
} 
berkepribadian yang mantap dan mandiri serta rasa tanggungjawab kemasyarakatan dan kebangsaan. ${ }^{22}$

Pembinaan dan praktek akhlak mulia yang memadai selama dua puluh empat jam di pondok pesantren telah diwarnai oleh nuansa keagamaan yang kondusif. Suasana yang demikian akan menjadi modal dasar bagi pondok pesantren dalam memelihara dan mempertahankan moral serta meneguhkan wawasan kebangsaan masyarakat Indonesia. ${ }^{23}$ Aktifitas pondok pesantren selama 24 jam yang dibimbing langsung oleh para pembina, membuat santri terbiasa dengan kehidupan yang serba disiplin, Disiplin waktu pada jadwal shalat,jadwal makan, jadwal sekolah, jadwal kegiatan olah raga,seni dan lain-lain. Dengan serangkaian kegiatan yang teratur selama 24 jam perhari akhirnya lama kelamaan membuat santri terbiasa dengan disiplin waktu dan terbiasa dengan aktifitas yang positif, sehingga menjadi sebuah pertahanan moral dan memperkaya wawasan pribadi santri. Pondok pesantren mempunyai posisi dan peran yang sangat sentral dalam mewujudkan kualitas budi pekerti yang tinggi, badan yang sehat, pengetahuan yang luas, dan pemikiran yang bebas, yang kelak akan diaplikasikan santri di masyarakat.

\section{Penutup}

Pesantren sebagai lembaga pendidikan Islam, dalam sejarah perkembangannya mengalami pasang surut dalam mengagapai tujuannya. Hal ini karena akibat dari penjajah yang tidak menginginkan Islam berkembang, selanjutnya tantangan dari kalangan masyarakat Indonesia yang takut bila Islam menguasai arah kebijakan Negara Indonesia. Awal abad ke-21 merupakan momen yang memberi peluang bagi lembaga pendidikan Islam untuk memperlihatkan dan memperjuangkan tujuan pendidikan Islam. Terbukti lahirnya UU No. 20 Tahun 2003, yang merupakan UU yang berpihak pada eksistensi pendidikan Islam di Indonesia.

Ada beberapa pasal dalam UU No. 20 Tahun 2003 yang menyinggung tentang pendidikan Islam. Di dalam aturan tersebut setidaknya ada tiga

\footnotetext{
${ }^{22}$ Lihat Ahmad Tafsir, op.cit., h. 200.

${ }^{23}$ Lihat Depag RI., Dinamika, op.cit., h. 17.
} 
hal yang terkait dengan pendidikan Islam. Pertama, kelembagaan formal, nonformal dan informal diposisikannya madrasah sebagai sebagai lembaga pendidikan formal yang diakui keberadaannya setara dengan lembaga pendidikan sekolah. Dan dipertegas pula eksistensinya sebagai sekolah yang berciri khas agama Islam, selanjutnya diakui majlis taklim sebagai pendidikan nonformal dan dipertegas juga eksistensi pesantren sebagai lembaga pendidikan keagamaan. Kedua, pendidikan Islam sebagai mata pelajaran agama sebagai salah satu mata pelajaran yang wajib diberikan kepada peserta didik di semua jalur, jenis dan jenjang pendidikan. Ketiga, pendidikan Islam sebagai nilai, terdapat seperangkat nilai-nilai Islami dalam sistem pendidikan nasional.

\section{DAFTAR PUSTAKA}

Aly, Machrus. Hakekat Cita Pondok Pesantren, dalam Mujamil Qomar, Pesantren dari Transformasi Metodologi Menuju Demokratisasi Institusi. Jakarta: Erlangga, tt.

Brugmans, I.J. 1938, Geschiedenis van het Onderwijs in Nederlandsc Indie (Sejarah Pendidikan di Hindia Belanda) Groningen.

Daulay, Haidar Putra, 2006, Pendidikan Islam Dalam Sistem Pendidikan Nasinal di Indonesia. Jakarta: Kencana.

Departemen Agama RI., Seri Monografi Penyelenggaraan Pendidikan Formal di Pondok Pesantren, Proyek Pembinaan dan Bantuan Kepada Pondok Pesantren 1984/1985.

-------,2005, Dinamika Pondok Pesantren Di Indonesia,Direktorat Pendidikan Keagamaan dan Pondok Pesantren. Direktorat Jenderal Kelembagaan Agama Islam, 2005.

------, 2007, Kumpulan Undang-Undang dan Peraturan Pemerintah RI tentang Pendidikan, Dirjen Pendidikan Islam Depaqg RI.

Rahim, Husni. 2001, Arah Baru Pendidikan Islam Di Indonesia. Jakarta: Logos Wacana Ilmu.

Maftuh Muhammad Basyuni, 2007, Revitalisasi Spirit Pesantren,gagasan kiprah dan refleksi, Jakarta: Direktorat Pendidikan Diniyah dan Pondok Pesantren. 
Ma'shum, Ali. 1995, Ajakan Suci, Editor Ismail S. Ahmad, M.Yoenus Noer, dan Nadirin. t.tp.: LTN-NU DIY

Muh. Said, dan Junimar Affan, 1987, Mendidik dari Zaman ke Zaman. Bandung: Jemmars

Wahjoetomo. 1997, Perguruan tinggi Pesantren: Pendidikan Alternatif Masa Depan. Jakarta: Gema Insani Press.

Zeni, A. Wahid. 1995, Dunia Pemikiran Kaum Santri. Editor M. Masykur Amin dan A. Malik Ridwan. Yogyakarta: LKPSM NU DIY 
